\title{
Idelalisib-induced pneumonitis
}

\author{
Arjun Gupta, ${ }^{1}$ Hsiao C Li ${ }^{2}$
}

${ }^{1}$ Department of Internal Medicine, University of Texas Southwestern Medical Center, Dallas, Texas, USA

${ }^{2}$ Harold C. Simmons Cancer Center, University of Texas Southwestern Medical Center, Dallas, Texas, USA

\section{Correspondence to}

Dr Arjun Gupta, guptaarjun90@gmail.com

Accepted 6 July 2016
CrossMark

To cite: Gupta A, Li HC. BMJ Case Rep Published online: [please include Day Month Year] doi:10.1136/ bcr-2016-216343

\section{DESCRIPTION}

A woman in her 40s with relapsed follicular lymphoma presented with a few days history of shortness There were no reported toxic exposures or contacts with sick people. Medications included idelalisib initiated 5 months ago and a multivitamin. Vital signs were notable for tachycardia and tachypnoea, oxygen saturation was $89 \%$ on room air. The alveolar-arterial gradient was $50 \mathrm{~mm} \mathrm{Hg}$ (expected for age, $16 \mathrm{~mm} \mathrm{Hg}$ ). Examination revealed diffuse crackles in bilateral lung fields. Routine biochemical investigations were unremarkable and multiple infectious studies were negative. Chest X-ray showed bilateral interstitial infiltrates. A CT scan of the chest demonstrated bilateral diffuse groundglass opacities and peribronchial thickening (figure 1A). Given the overall clinical picture, a diagnosis of acute lung injury secondary to idelalisib-induced pneumonitis was considered. Idelalisib was discontinued and she was treated with empiric antibiotics (until the cultures returned negative). High-dose intravenous steroids were initiated with resolution of symptoms and she was discharged home with a 3 week prednisone taper. A repeat CT scan 3 months later showed complete resolution of lung infiltrates (figure 1B). She opted for not restarting idelalisib therapy.

Idelalisib is a molecular agent approved for the treatment of relapsed chronic lymphocytic leuke$\mathrm{mia} / \mathrm{small}$ lymphocytic lymphoma and relapsed follicular B-cell non-Hodgkin lymphoma. ${ }^{1}$ By potentially interfering with the regulatory immune system, it has been associated with causing colitis, dermatitis, transaminitis and pneumonitis. ${ }^{1}$ Prescribing information recommends that patients presenting with cough, dyspnoea, hypoxia, interstitial infiltrates or a decline in oxygen saturation by $>5 \%$ should be evaluated for pneumonitis. ${ }^{2}$ Idelalisib is considered to have caused pneumonitis of breath and cough producing yellow sputum.

in $\sim 2 \%$ of patients who were being treated with this drug for relapsed indolent lymphoma, in the original phase 2 clinical trial. ${ }^{3}$ Idelalisib treatment should be suspended if pneumonitis is suspected. Corticosteroids have been successful in treating pneumonitis in clinical trials.

\section{Learning points}

Idelalisib is a selective, phosphatidylinositol 3-kinase delta (PI3Kd) inhibitor approved for the treatment of relapsed chronic lymphocytic leukemia/small lymphocytic lymphoma and relapsed follicular B-cell non-Hodgkin lymphoma.

- Although it is a rare cause, Idelalisib is known to be associated with severe pneumonitis. Discontinuation of the drug and initiating high-dose corticosteroids might help to reverse this serious and sometimes fatal adverse event.

Contributors $A G$ and $\mathrm{HCL}$ were involved in the conception and design, acquisition and analysis of data, drafting the article or revising it critically for important intellectual content and gave final approval of the version published.

Competing interests None declared.

\section{Patient consent Obtained.}

Provenance and peer review Not commissioned; externally pee reviewed.

\section{REFERENCES}

1 http://www.accessdata.fda.gov/drugsatfda_docs/label/2014/ 206545lbl.pdf

2 ZYDELIG (idelalisib tablets). Full prescribing information. Foster City, CA: Gilead Sciences, Inc., 2014.

3 Gopal AK, Kahl BS, de Vos S, et al. PI3K $\delta$ inhibition by idelalisib in patients with relapsed indolent lymphoma. $N$ Engl J Med 2014;370:1008-18.

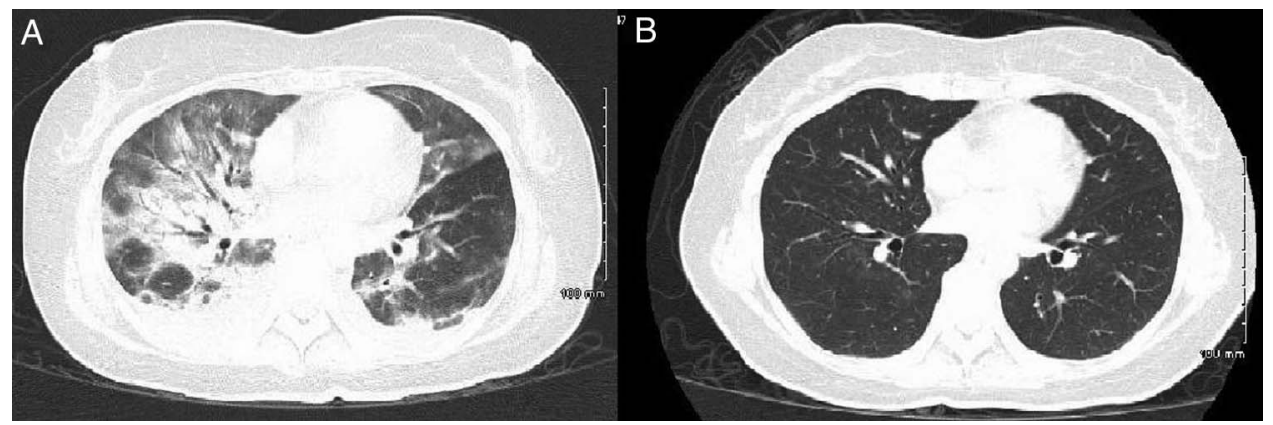

Figure 1 CT scans of the chest at presentation (A) showing diffuse groundglass opacities and peribronchial thickening with resolution of these infiltrates 3 months later after therapy with corticosteroids (B). 
Copyright 2016 BMJ Publishing Group. All rights reserved. For permission to reuse any of this content visit http://group.bmj.com/group/rights-licensing/permissions.

BMJ Case Report Fellows may re-use this article for personal use and teaching without any further permission.

Become a Fellow of BMJ Case Reports today and you can:

- Submit as many cases as you like

- Enjoy fast sympathetic peer review and rapid publication of accepted articles

- Access all the published articles

- Re-use any of the published material for personal use and teaching without further permission

For information on Institutional Fellowships contact consortiasales@bmjgroup.com

Visit casereports.bmj.com for more articles like this and to become a Fellow 